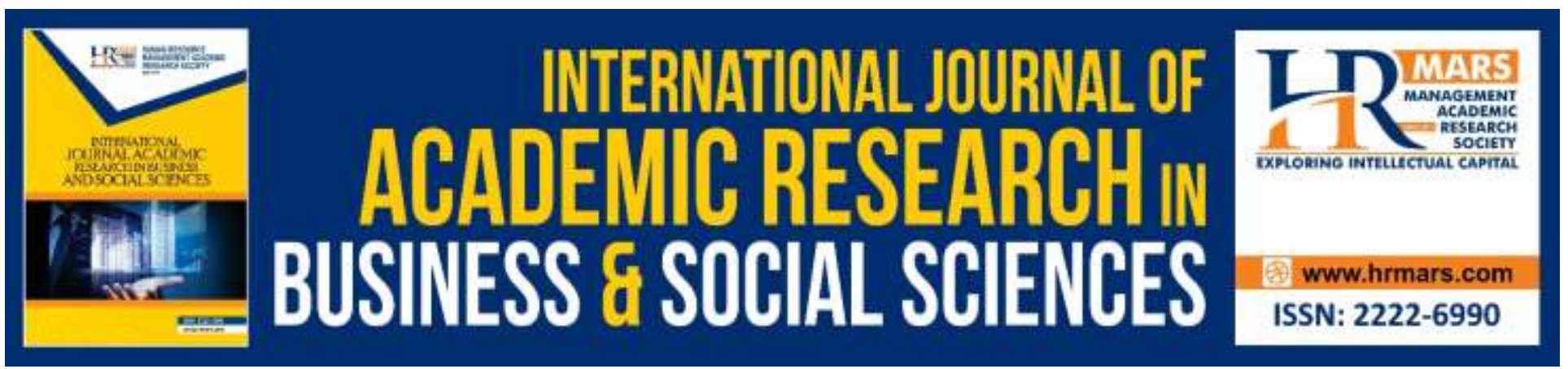

\title{
M-Learning: Spatial Atomic Orbital for Stem
}

L S Ang, S. S. M. Fauzi, M Umi Hanim, A. Amin Zhafran, S. Suhaimi and M. N. N. Najwa-Alyani

To Link this Article: http://dx.doi.org/10.6007/IJARBSS/v9-i14/6836

DOI: $10.6007 /$ IJARBSS/v9-i14/6836

Received: 22 August 2019, Revised: 17 September 2019, Accepted: 05 October 2019

Published Online: 22 October 2019

In-Text Citation: (Ang et al., 2019)

To Cite this Article: Ang, L. S., Fauzi, S. S. M., Hanim, M. U., Zhafran, A. A., Suhaimi, S., \& Najwa-Alyani, M. N. N. (2019). M-Learning: Spatial Atomic Orbital for Stem. International Journal of Academic Research in Business and Social Sciences, 9(14), 145-152.

Copyright: (C) 2019 The Author(s)

Published by Human Resource Management Academic Research Society (www.hrmars.com)

This article is published under the Creative Commons Attribution (CC BY 4.0) license. Anyone may reproduce, distribute, translate and create derivative works of this article (for both commercial and non-commercial purposes), subject to full attribution to the original publication and authors. The full terms of this license may be seen at: http://creativecommons.org/licences/by/4.0/legalcode

Vol. 9, No. 14, Special Issue: Education 4.0: Future Learning, Pg. 145 - 152

Full Terms \& Conditions of access and use can be found at http://hrmars.com/index.php/pages/detail/publication-ethics 


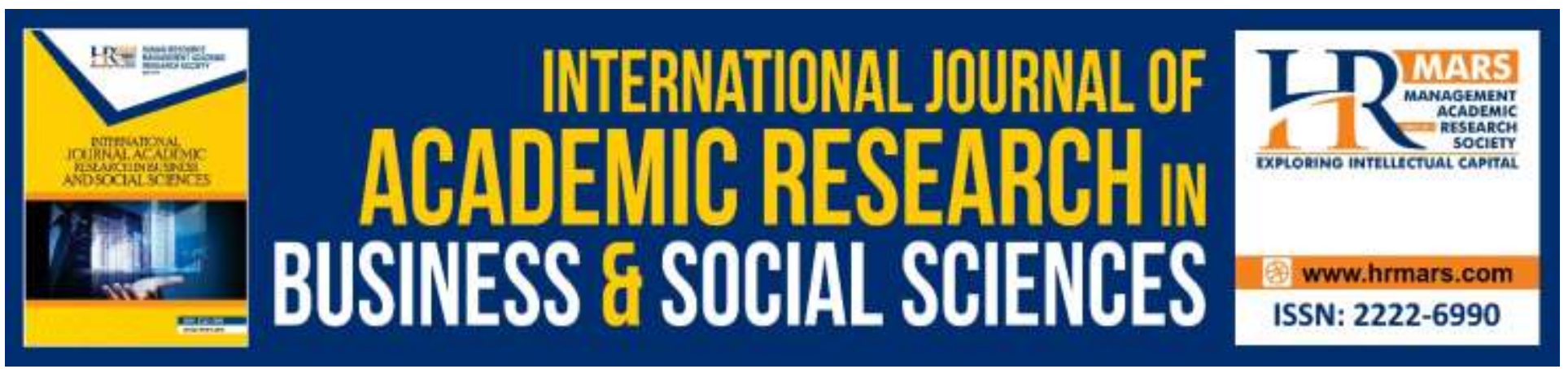

\title{
M-Learning: Spatial Atomic Orbital for Stem
}

\author{
L S Ang ${ }^{1}$, S S M Fauzi², M Umi Hanim², A Amin Zhafran², S \\ Suhaimi $^{3}$ and $M$ N N Najwa-Alyani ${ }^{1}$ \\ ${ }^{1}$ Faculty of Applied Sciences, Universiti Teknologi MARA (Cawangan Perlis), Perlis, Malaysia, \\ 2 Faculty of Computer and Mathematical Sciences, Universiti Teknologi MARA (Cawangan Perlis), \\ Perlis, Malaysia, ${ }^{3}$ Faculty of Art, Computing and Creative Industry, Universiti Pendidikan Sultan Idris, \\ Malaysia. \\ Email: anglee631@perlis.uitm.edu.my, shukorsanim@perlis.uitm.edu.my \\ suhazlan@fskik.upsi.edu.my
}

\begin{abstract}
Downward trend of student's enrolment in science and health studies is an issue that should not be taken lightly. This is due to the decrease in the workers in these science-related fields may jeopardise the successful implementation of government's agenda in alleviating Malaysia's performance in the world stage. In this paper, mobile application named SPATO, a teaching aid in the learning of atomic orbitals of elements in the Periodic Table is presented. SPATO is developed with the aim to spur the interest of community in studying the science-related subjects in the guise as a mobile-learning tool. The Waterfall Model was used to fulfill the aims in the development of this mobile application. Expert reviewers were involved in the testing of this mobile-learning tool using TAM model. From the distributed questionnaire, SPATO had shown to be well accepted by the users as all the categories show positive results. Users found that it is easy to use, even though initially they might not familiar with the m-learning application. SPATO provides a platform for the community to engage themselves to the topic of atomic orbitals. Results from the acceptance testing show that SPATO can function as an alternative approach in understanding the chemical elements.
\end{abstract}

Keywords: M-Learning, Applications, Atomic Orbital, Periodic Table.

\section{Introduction}

The number of student enrolled in the field of science and health studies had been reported to be decreasing, indicating the interest in the study in science field is dwindling in Malaysia (Meng, Idris, \& Eu, 2014). However, since Malaysia have aims to become a developed country as in the TN50 plan (Transformasi Nasional 50), the importance of the science, technology, engineering, and mathematics (STEM) studies cannot be overstated (Phang, 2017; Sipon, 2017; Tyasari, Yusof, Bahador, 2018). Providing effective learning solutions through mobile delivery involves multiple disciplines, and in this regard, a wide range of technologies are considered to be able to attract 
student to the studies in the science-related fields. Ratio of students that have a mobile phone is increasing from every year. Nowadays, rapid growth of the advancement with mobile technologies is seen as new opportunities to incorporate the latest innovation in the digital front for teaching and learning process. However, compared to the computer-based educational software and simulation, studies using the mobile application are still new to the education world. Indeed, some of the educational applications had shown to contribute and enhanced the effectiveness in teaching and shaping the characteristics of societies (Falloon, 2013; Wu, Lee, Chang, \& Liang, 2013). Mobile application is preferable to attract target community in the learning topic of interest by providing a flexible platform. It is an alternative way to support the traditional methods in teaching, in which the amount of time spent on a topic could be increased (Ting, 2005; Tyasari, Yusof, Bahador, 2018).

Mobile learning, also known as M-learning, is defined as the learning process by using the mobile devices, such as smartphones. It is also known as "e-learning using mobile devices" (Pinkwart, Hoppe, Milrad, \& Perez., 2003). Learning through M-learning can be considered as an interactive aid to the existing methods. M-Learning is supported by a variety of mobile communication platform such as communicate using voice, surfing to the learning portal on the Internet and learn on platform Short Message Service (SMS) (Ting, 2005). This shows that M-Learning could be an interactive learning platform with the combination of audio, portal web and mobile phone technologies in one package.

For studies in the science-related fields, one of the widely used basic information is the atomic orbitals of the chemical element of the Periodic Table (PT). PT is widely used due to the important information that is usually incorporated in it. Printable PT are available in the internet and text books, providing flexibility and convenient for the users. However, due to the limitation of space, not all properties of element are included in those sources. One of them is atomic orbital, which is a space where the electrons have a chance to be found. It is known as a basic topic that usually thought in the introductory chemistry classes (Autschbach, 2012; Tsaparlis, 1997). While for some other countries, it is a part of the secondary school syllabus (Tsaparlis, 1997). Thus, many approaches are created to portray the existence of the atomic orbital for PT elements. It is ranging from using marbles and papers (Specht \& Raley, 2014), software (Bonifácio, 2012; Ramachandran \& Kong, 1995) to the three dimension printer (Griffith, Cataldo, \& Fogarty, 2016).

In the current report, atomic orbitals have been obtained from quantum-mechanical calculations (e.g., using software Gaussian (Frisch et al., 2016)). The atomic orbital was then presented using a mobile application SPATO (SPatial ATomic Orbitals) with certain properties. This mobile application will allow the users to view image of the atomic orbital's surface and also compared the size of atomic orbital between the elements from the PT.

\section{Methodology}

Developing Research Questions

Few research questions were created in order to achieve the objective in developing the mobile learning of atomic orbital for PT elements:

RQ1: Is the mobile application suitable for the community to access in learning?

RQ2: Is it possible for SPATO to stimulate the community's interest in studying science? 
INTERNATIONAL JOURNAL OF ACADEMIC RESEARCH IN BUSINESS AND SOCIAL SCIENCES

Vol. 9, No. 14, Special Issue: Education 4.0: Future Learning. 2019, E-ISSN: 2222-6990 @ 2019 HRMARS

\section{Choose Models Used}

To fulfil the aims of this study, Waterfall model was used, in which to proceed to the next phase of the Waterfall model, previous phase need to be complete (Balaji \& Murugaiyan, 2012). The Waterfall model consists of analysis, design, implementation and testing phases, as shown in Figure 1 (Bassil, 2012).

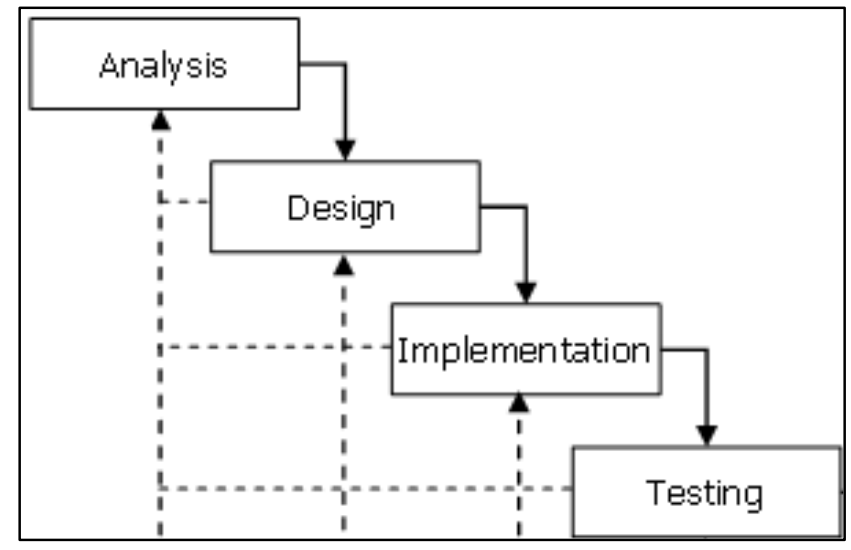

Figure 1. The waterfall model. (Bassil, 2012)

Each phases of the development for this project, shown in Figure 1, is elaborated further in the following sections:

Analysis - The information for the development of mobile application were collected from online sources, article, journal and online databases, and were analysed and recorded.

Design - The existing interface of another application that is being used for the PT was used as reference in order to fulfill the users' requirements. Storyboard was organized using the Adobe Photoshop software which includes two different options which are

A: To view the atomic orbital of the PT

B: To compare the atomic orbitals of the PT.

Implementation - The project was then developed based on the input collected during the analysis and design phases. Java language was used as the source code to develop the mobile's interface links and functions. The library used is based on the Android library provided by Android Studio software. The atomic orbitals viewed in this mobile application are generated using Gaussian 09 (Frisch et al., 2016) and Multiwfn (Lu \& Chen, 2012) software. The Gaussian 09 is used to generate the atomic orbital of the chemical elements through the quantum mechanical calculations. The outputs from the calculations were fed to Multiwfn, which provides the coloured atomic orbital with scales overlapping the atomic orbital. The interface was then developed using the Android Studio, Genymotion, Balsamiq and Adobe Photoshop CS5 
INTERNATIONAL JOURNAL OF ACADEMIC RESEARCH IN BUSINESS AND SOCIAL SCIENCES

Vol. 9, No. 14, Special Issue: Education 4.0: Future Learning. 2019, E-ISSN: 2222-6990 @ 2019 HRMARS

Testing - Functional testing and acceptance testing are applied to validate the SPATO functions and acceptance of the users to SPATO application. Functional testing is aimed for a better performance to meet the requirements which includes:

1. Show list of 18 elements based on the periodic table.

2. List the type of orbitals for each element.

3. Zooming properties for the image of atomic orbital.

For the acceptance testing, the questionnaire was constructed to examine the m-learning interest of the research participant on this mobile application using the Technology Acceptance Model (TAM) (Dumpit \& Fernandez, 2017). The candidates for the testing include the expert reviewers from the science-related field.

\section{Results and Discussion}

\section{Interface of the SPATO application}

The final design of the SPATO application is as shown in Figure 2. In Figure 2(a), two different buttons were developed to indicate different options. "Explore" button would provide the detailed information about the chemical elements and the atomic orbital of the element. The "Explore" button will lead to a page with 18 different buttons indicating 18 different elements in PT as shown in Figure 2(b). All of these 18 buttons would lead to another page with the information of the chemical elements (Figure 2(c)). The atomic orbital and information is placed side by side. The atomic orbitals included in this page also has a button to go to another page. Figure 2(d) shows the interface of the atomic orbitals for the chemical elements. This interface provides the zooming option of the molecular orbital. The name and coordinates overlapped the atomic orbital for better understanding of the size of the atomic orbital of the chemical elements.

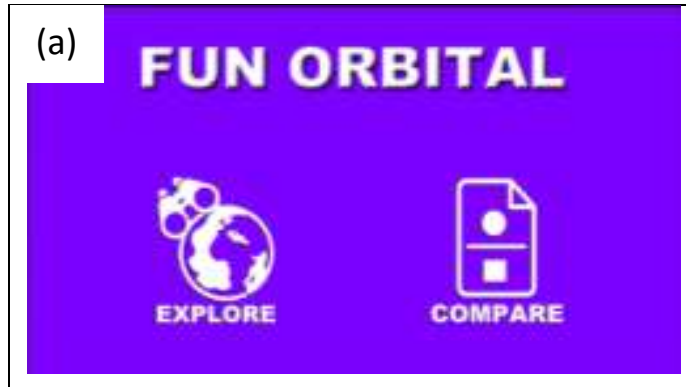

(c)

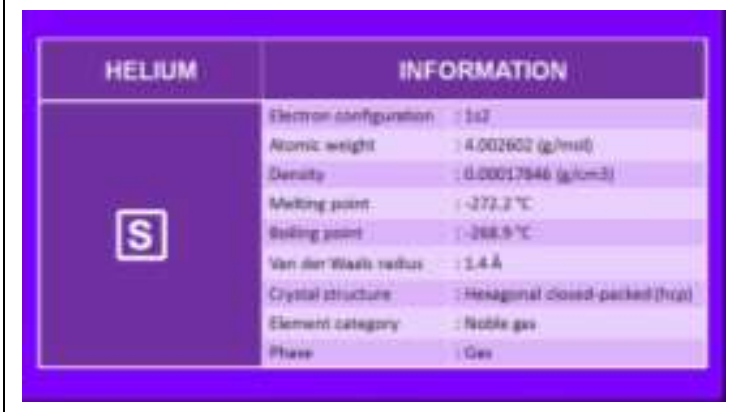

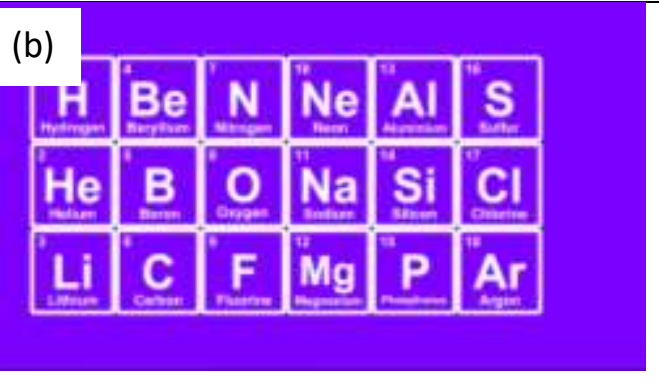

(d)

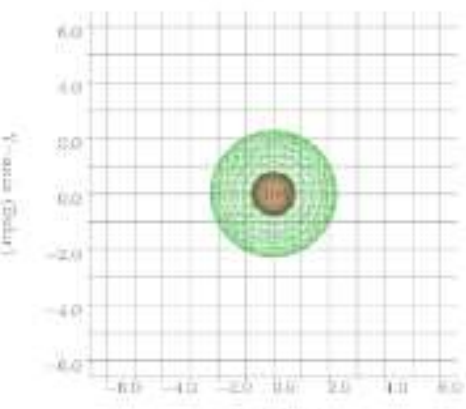

Figure 2. Interface of the application in (a) front page, (b) elements provided, (c) details of element and (d) molecular orbital of element. 
INTERNATIONAL JOURNAL OF ACADEMIC RESEARCH IN BUSINESS AND SOCIAL SCIENCES

Vol. 9, No. 14, Special Issue: Education 4.0: Future Learning. 2019, E-ISSN: 2222-6990 @ 2019 HRMARS

The "Compare" button as shown in Figure 2(a) would lead to another interface where a list of chemical elements will be shown. To compare two different elements, Figure 2(b) would appear for second time for selection of second element that wants to compared to. Last interface would show the two different elements put side by side as in Figure 3. Same zooming option was provided to the users. The coordinate scale is similar for a better comparison of the atomic orbitals.

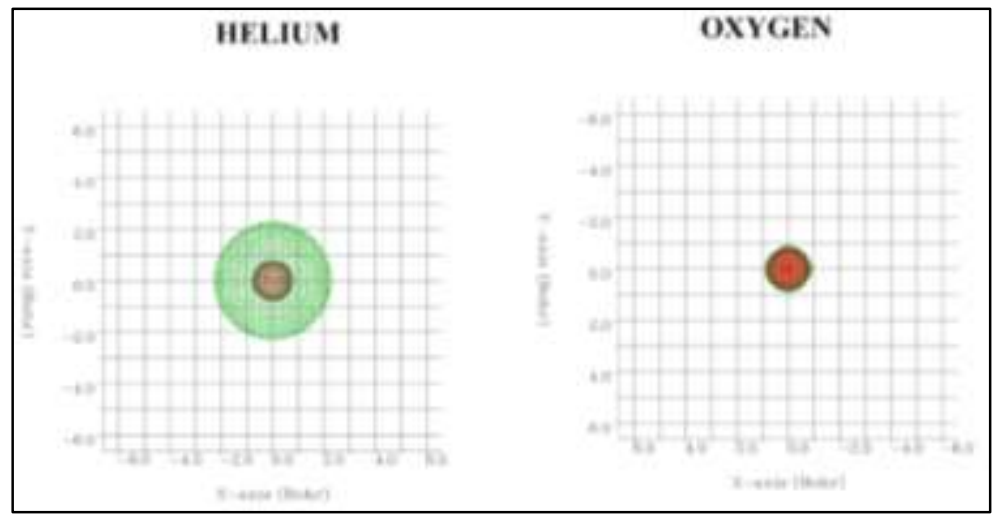

Figure 3: The comparison of molecular orbital page.

\section{Functional Testing}

Functional testing was done with a module as tabulated in Table 1. From the results of the functional test, it can be concluded that the SPATO is easy to use. The users found that it is easy to navigate through this mobile application, even though majority of them are not familiar at first with the Mlearning application. From the observation, there were no users facing any problem when using the application in the testing phase.

Table 1. Functional Testing

\begin{tabular}{llll}
\hline $\begin{array}{l}\text { Test } \\
\text { ID }\end{array}$ & Modules & Expected Results & Results \\
\hline 1 & $\begin{array}{l}\text { Show list of } 18 \\
\text { elements based on } \\
\text { the PT. }\end{array}$ & $\begin{array}{l}\text { Users choose an element to learn the atomic } \\
\text { orbital shape and information. }\end{array}$ & Good \\
2 & $\begin{array}{l}\text { List the type of } \\
\text { orbital for each } \\
\text { element The user chooses the type of orbital. }\end{array}$ & Good \\
& $\begin{array}{l}\text { Zooming properties } \\
\text { for the image of } \\
\text { atomic orbital }\end{array}$ & $\begin{array}{l}\text { The user is able to zoom the image to view } \\
\text { orbitals. }\end{array}$ & \\
\hline
\end{tabular}

\section{Acceptance Testing}

For acceptance testing, respondent are from group of expert reviewers where the questionnaire are being distributed to each of them individually. Respondent was asked to use the mobile application without being assist by the SPATO developer. By using TAM, overall mean was classified as in Table 2. There are positive, negative, and neutral categories, with values in between zeros to five. 
INTERNATIONAL JOURNAL OF ACADEMIC RESEARCH IN BUSINESS AND SOCIAL SCIENCES

Vol. 9, No. 14, Special Issue: Education 4.0: Future Learning. 2019, E-ISSN: 2222-6990 @ 2019 HRMARS

Table 2. Range of mean.

\begin{tabular}{ll}
\hline Category & Range of Mean \\
\hline Negative & $0-1.66$ \\
Neutral & $1.67-3.33$ \\
Positive & $3.34-5$ \\
\hline
\end{tabular}

As shown in Table 3, the overall mean for the acceptance test using TAM is 4.16. This concludes that for each category tested, positive feedbacks were obtained from the users. This answers the RQ2 where the reviewers agree that SPATO application can provide enhancement in student knowledge on element of PT. For perceive usefulness category, the mean is 4.05 where reviewers agree that the information provided by the SPATO are enough for basic information and is beneficial to the users. SPATO had been considered as user-friendly and attractive, as navigation is clearly defined, as the perceived ease of use had mean result of 4.30. Reviewers also agree that SPATO is easy to understand and the design of the SPATO application is acceptable for the users as attitude toward usage reach 4.25. Lastly, behavioural intention to use the SPATO is 4.05 as the reviewer comment that SPATO is easily assessed from any devices; reviewers are interested to use SPATO for their platform in learning and teaching.

Table 3. Acceptance testing TAM result

\begin{tabular}{lcccl}
\hline TAM Category & Min & Max & Mean & $\begin{array}{l}\text { Mean } \\
\text { Category }\end{array}$ \\
\hline Perceive Usefulness & 3.90 & 4.20 & 4.05 & Positive \\
Perceived Ease of Use & 4.10 & 4.50 & 4.30 & Positive \\
Attitude Toward Usage & 4.10 & 4.40 & 4.25 & Positive \\
Behavioral Intention to Use & 4.00 & 4.10 & 4.05 & Positive \\
\hline
\end{tabular}

\section{Conclusions}

SPATO mobile application was developed to provide effective learning of atomic orbitals of the elements in the PT, with the aim to spur the interests of the community to study science-related courses. This mobile application had shown to function well as being tested repetitively by the users. It has achieved the objective to stimulate the community's interest on the atomic orbital of the PT elements as $100 \%$ of the TAM acceptance testing shows positive results. This had proved the effectiveness of the mobile learning for learning and teaching related to sciences and technology. The SPATO mobile application will be improved in the future. (Kuan \& Tiekink, 2007; Usaini \& Abubakar, 2015)

\section{References}

Autschbach, J. (2012). Orbitals: Some Fiction and Some Facts. J. Chem. Edu., 89(8), 1032-1040.

Balaji, S., \& Murugaiyan, M. S. (2012). Waterfall vs. V-Model vs. Agile: A Comparative Study on SDLC. Int. J. Info. Tech. Man., 2(1), 26-30.

Bassil, Y. (2012). A Simulation Model for the Waterfall Software Development Life Cycle. Int. J. Engin. \& Tech., 2(5), 1-3. 
INTERNATIONAL JOURNAL OF ACADEMIC RESEARCH IN BUSINESS AND SOCIAL SCIENCES

Vol. 9, No. 14, Special Issue: Education 4.0: Future Learning. 2019, E-ISSN: 2222-6990 @ 2019 HRMARS

Bonifacio, V. D. B. (2012). QR-Coded Audio Periodic Table of the Elements: A Mobile-Learning Tool. J. Chem. Edu., 89(4), 552-554.

Dumpit, D. Z., \& Fernandez, C. J. (2017). Analysis of the use of social media in Higher Education Institutions (HEIs) using the Technology Acceptance Model. Int. J. Math. Educ. Sci. Technol., 14(1), 5.

Falloon, G. (2013). Young students using iPads: App design and content influences on their learning pathways. Comput Educ, 68, 505-521.

Frisch, M. J., Trucks, G. W., Schlegel, H. B., Scuseria, G. E., Robb, M. A., Cheeseman, J. R., . . Fox, D. J. (2016). Gaussian 09. Gaussian, Inc., Wallingford CT.

Griffith, K. M., Cataldo, R. d., \& Fogarty, K. H. (2016). Do-It-Yourself: 3D Models of Hydrogenic Orbitals through 3D Printing. J. Chem. Edu., 93(9), 1586-1590.

Kuan, F. S., \& Tiekink, E. R. T. (2007). N,N'-Di-o-tolylthiourea. Acta Crystallographica Section E, 63(12), 04692.

Lu, T., \& Chen, F. (2012). Multiwfn: A Multifunctional Wavefunction Analyzer. J. Comput. Chem., 33(5), 580.

Meng, C. C., Idris, N., \& Eu, L. K. (2014). Secondary Students' Perceptions of Assessments in Science, Technology, Engineering, and Mathematics (STEM). EURASIA J. Math. Sci Tech., 10(3), 219227.

Phang, F. A. (2017, 16 June 2017). STEM boleh jayakan agenda TN50. Berita Harian.

Pinkwart, N., Hoppe, H. U., Milrad, M., \& Perez., J. (2003). Educational Scenarios for the Cooperative Use of Personal Digital Assistants. J. of Comp. Ass. Learn., 19, 383-391.

Ramachandran, B., \& Kong, P. C. (1995). Three-Dimensional Graphical Visualization of One-Electron Atomic Orbitals. J. Chem. Edu., 72(5), 406.

Sipon, S. (2017, 21 July 2017). STEM penuhi impian jadi negara pencipta. Berita Harian.

Specht, Z., \& Raley, D. (2014). Modeling Electron Density and Atomic Orbitals Using Marbles and Carbon Paper: An Exercise for High School Students. J. Chem. Edu., 91(1), 151-153.

Ting, R. Y.-L. (2005, 5-8 July 2005). Mobile learning: current trend and future challenges. Paper presented at the Fifth IEEE International Conference on Advanced Learning Technologies (ICALT'05).

Tsaparlis, G. (1997). Atomic orbitals, molecular orbitals and related concepts: Conceptual difficulties among chemistry students. Res. Sci. Edu., 27(2), 271.

Wu, H.-K., Lee, S. W.-Y., Chang, H.-Y., \& Liang, J.-C. (2013). Current status, opportunities and challenges of augmented reality in education. Comput. Educ., 62, 41-49.

Abdullah, C. Z. H., Daud, S. C., Ariff, N. Z. Z. M., \& Shaifuddin, N. (2018). Bibliographic Control and Resource Description Access Standard in Malaysia. International Journal of Academic Research in Progressive Education and Development, 7(3), 96-102.

Usaini, M. I., \& Abubakar, N. B. (2015). The Impact of Parents' Occupation on Academic Performance of Secondary School Students in Kuala Terengganu. Multilingual Academic Journal of Education and Social Sciences, 3(1), 112-120.

Tyasari, I., Yusof, N. Z. M., Bahador, K. M. (2018). Indonesia's Participation in ASEAN Audit Regulators Group (AARG): Efficiency-driven or Institutional Pressure? International Journal of Academic Research in Accounting, Finance and Management Sciences 8 (3): 299-309. 